\title{
INTERNATIONAL WORKING CAPITAL PRACTICES OF GHANAIAN FIRMS
}

\author{
J Abor, University of Ghana Business School - Legon
}

\begin{abstract}
International working capital management is important to firms frequently operating in the international market. This article investigates the international working capital practices of top Ghanaian firms involved in international trade. The objective of the study is to ascertain the extent to which Ghanaian firms use international working capital management vehicles. The article focuses on two main areas of international working capital management; international cash management and international sales and accounts receivables management. The results of this study reveal low level of use of international working capital vehicles among Ghanaian firms. Recommendations are made in this regard.
\end{abstract}

Keywords and phrases: international, working capital, practices, Ghana

\section{INTRODUCTION}

Working capital management is an integral component of the overall corporate strategy to create shareholder value (Shin \& Soenen, 1998). Working capital management is defined broadly to encompass all aspects of the administration of both current assets and current liabilities (Baker, 1987). The decisions about a firm's current assets and current liabilities are required to plan and control the flow of funds among various working capital accounts and other balance sheet accounts to ensure adequate liquidity for the firm and to also enhance the firm's profitability (Baker, 1987; Shin \& Soenen, 1998).

A basic tenet of corporate finance theory is that firms will engage in those behaviours and activities that maximise the market value of the firm's common stock at some acceptable level of risk. Such behaviours and actions can be broadly identified as those that have positive benefitcost analyses (Ricci \& Morrison, 1996). According to Ricci and Vito (2000), the purpose of working capital management is to manage the firm's current accounts to attain a desired balance between profitability and risk. Abor (2004) confirms that efficient management of working capital results in increased shareholder value. To enhance profitability, Hill \& Sartoris (1992) suggest reducing time value costs of the float (i.e. the opportunity cost of the amount of money tied up between the time when debtors initiate payment and the time when the funds become available for use in the bank account), credit losses due to the inability to collect payments, transaction costs of moving cash within and between other countries, and losses on foreign exchange conversions.

There has been enormous growth in recent times in the number of firms engaged in international business. Firms are internationalising their operations either through international trade (export and import) or through the establishment of subsidiaries in foreign markets. This trend is expected to continue as more firms discover that their overseas operations can contribute strongly to their profitability (Ricci \& Morrison, 1996). This means firms frequently operating on the international market would constantly be confronted with international working capital management decisions. Despite the increasing importance of international working capital 
management, there is limited research in the area. The few studies (see Collins \& Frankle, 1985; Ricci \& Morrison, 1996; Ricci \& Vito, 2000) tend to focus mainly on the developed economies especially the UK and US. The absence of empirical evidence on the issue from the context of developing countries has necessitated the need for this study. This present study seeks to investigate the international working capital practices of Ghanaian firms. The study focuses on ascertaining the extent to which Ghanaian firms use international working capital management vehicles.

The article is organised as follows: Section 2 discusses the conceptual framework of international working capital management. Section 3 explains the methodology adopted for the study. The empirical results are presented and discussed in section 4. Finally, section 5 summarises and concludes the discussion.

\section{CONCEPTUAL FRAMEWORK}

International working capital management basically centers on International Cash Management and International Sales and Accounts Receivables Management. These concepts are discussed in turn.

\section{International Cash Management Operations}

International cash management is concerned with how firms manage their cash in respect of international transfers and settlements. Methods used in such transfers and settlements include Wire Transfers, Electronic Funds Transfer, Payments Netting and Cash Pooling.

\section{Wire Transfers}

Two computerized systems have been developed to process international wire transfers. These are CHIPS and SWIFT. CHIPS (Clearing House Interbank Payment System) is a payment system used primarily by large domestic and foreign banks in New York City that clears most dollar-denominated international transfers. SWIFT (Society for Worldwide Interbank Financial Telecommunications) is not a settlement system, but a communications system that connects banks in North America, Europe and the Far East. A primary benefit offered by SWIFT lies in the standardisation of the transfer process, which significantly reduces errors by providing a singular means of communication between correspondent banks. In addition, SWIFT has evolved into one of the least costly, most secure, and most rapid means of transmitting instructions (Aggarwal \& Baker, 1991).

\section{Electronic Funds Transfers}

An Electronic Fund Transfer (EFT) involves the transfer of funds initiated through an electronic terminal, telephone, computer or magnetic tape that instructs a financial institution to either credit or debit a customer's asset account. Examples of EFT services include Automated Teller Machine (ATM) transfers, direct deposits or withdrawals of funds, transfers initiated by telephone, and Point of Sale (POS) terminal transfers. The use of EFTs has grown rapidly in recent years. In 1985 , international EFTs were estimated at $\$ 72$ trillion; by 1990 , this figure had increased to $\$ 114$ trillion (Cunningham \& Porter, 1992). By 1991, the use of EFTs by businesses in the U.S. amounted to approximately $\$ 2$ trillion per day (Kress, 1991). A number of important characteristics make EFTs extremely valuable to businesses. Firstly, funds are moved faster and more efficiently than with cheques, so the float is decreased. Moreover, EFTs are completed at a 
relatively low cost that does not vary widely depending on the amount of the transfer because the price charged reflects primarily the cost of the mechanical aspects of the funds transfer (Kress, 1991).

\section{Payments Netting}

This system is used in international transactions by multinational companies and it involves reducing fund transfers between affiliates to only a netted amount. It requires the firm to have a centralised organisation of its cash management. There are basically two forms of payments netting. These include bilateral and multilateral netting. Bilateral netting involves the transfer of a netted amount between two affiliates. Bilateral payment is valuable only to the extent that subsidiaries sell back and forth to each other (Shapiro, 1978). Multilateral netting involves the transfer of a netted amount among three or more affiliates. The use of payments netting reduces the physical flow of funds from one subsidiary to another. As a result, measurable costs such as the cost of purchasing foreign exchange, the opportunity cost of the float (time in transit) and other transaction costs are minimised or eliminated. Netting systems are set up to reduce the costs associated with inter-affiliate cash transfers that result from business transactions. The payoff from multilateral netting systems can be large relative to their expense (Bogusz, 1993; Shapiro, 2002).

\section{Cash Pooling}

This is centralising the cash positioning functions to gain operational benefits. Thus subsidiaries hold minimum cash for their own transactions and no cash for precautionary purposes. All excess funds are remitted to a central cash depository. Cash pooling is the aggregation of affiliates' cash balances in excess of minimum operating requirements into a centralised account. The drawback to pooling is that the firm's subsidiaries have less control over their cash flows since all cash not needed for transaction purposes is transferred to the pool. One benefit is that, since all precautionary balances are held in the pool, the total level of such balances held by the firm as a whole can be reduced as long as the operating units of the firm are reasonably independent of each other. Secondly, pooling offers significant benefits regarding the financing or investment of shortages or surpluses of funds. Since cash surpluses of certain affiliates can be used to offset the deficits of others, the firm's total borrowings can be reduced. Moreover, aggregated surpluses can command higher interest rates because the investment transaction size will be larger.

\section{International Sales and Collections Activities}

This deals with the various ways by which firms export to their foreign customers and how foreign receivables are managed (i.e. means by which collections or payments are received from customers). Foreign sales methods include Open Account and Consignment while the collections systems include; Letters of credit, Sight and Time Drafts, Documentary Collections, Lock Boxes, Giro Payments, Cash in Advance, Value Dating and International Factoring.

\section{Open Account}

This involves shipping the goods to the importer, invoicing him and trusting him to pay within the prescribed limits. Payment may be made by draft, by cheque, or by bank transfer (Clark, Levasseur \& Rousseau, 1993). This can be a convenient method of payment in a foreign transaction if the buyer is well established, has a long and favourable payment record or has been thoroughly checked for credit worthiness. Importers prefer open account terms over many 
other methods of payment because open account sales offer simplified, flexible purchase procedures. In addition, it costs less for importers when compared to other methods such as letters of credit. Moreover, the open account method of payment is the most secure method for importers since they have power over both the goods and the funds. For exporters, selling on open account may improve an exporter's competitiveness since importers prefer purchases on open account. Also, coordination with banks is not required with open account resulting in savings on bank charges for exporters. The disadvantage to the exporter is that the absence of documents and banking channels might make it difficult to pursue the legal enforcement of claims. Open account terms are costly to exporters since they must finance the goods sold until payment is received. Also, open account terms yield increased risk to exporters due to currency controls and non-completion risk (Shapiro, 2002; Wagner \& Schumacher, 1994). In fact, shipping goods on open account is one of the riskiest methods of trade for exporters because of the lack of formal documentation regarding the sale.

\section{Consignment}

Selling on consignment involves shipping goods to the importer but maintaining title to them until they have been sold to a third party (Clark, Levasseur \& Rousseau, 1993). In this kind of arrangement, the importer does not make payment until after he has sold them. Consignment sales offer both advantages and disadvantages. From the exporter's standpoint, consignment sales are advantageous in that the exporter's marketing area can be expanded even when the exporter cannot find an importer to purchase his/her goods. However, consignment sales are extremely risky to the exporter for several reasons. Firstly, the exporter bears the financial risk for the goods until the merchandise is sold by the importer. Additionally, the seller must be concerned about the availability of foreign exchange in the importer's country because importers will give priority to merchandise covered by documentary drafts over goods shipped on consignment (Shapiro, 2002). Insurance can be purchased to guard against credit risk and political risk affecting consignment sales but the cost of this insurance, of course, reduces the exporter's profits (Brown, 1989; Williams, 1988).

\section{Letters of Credit}

A Letter of Credit (LC) is an instrument issued by a bank on behalf of the importer (buyer) promising to pay the exporter (beneficiary) upon presentation of shipping documents in compliance with the terms stipulated therein. The LC process normally involves two banks; the exporter's bank and the importer's bank. The issuing bank is substituting its credit for that of the importer. It essentially guarantees payment to the exporter provided the exporter complies with the terms and conditions of the LC. While LC may be used domestically, they are most commonly used internationally. There are basically two types of LCs; a revocable and an irrevocable LC. A revocable LC can be cancelled or revoked at any time without prior notification to the beneficiary and it is seldomly used. An irrecoverable LC on the other hand cannot be cancelled without the consent of the beneficiary. Thus an irrecoverable LC obligates the issuing bank to honour all drawings presented in conformity with the terms of the LC. The bank issuing the LC makes payment once the required documents have been presented in accordance with the payment terms.

Letters of Credit offer a number of advantages to both exporters and importers. It significantly reduces credit risk for the exporter since the LC means that payment is certified by a bank. Also, it facilitates access to pre-export financing. A bank is most likely to lend the exporter funds to process and prepare the merchandise for shipping if the LC is spotted or seen. In the case of the 
importer, he/she does not have to pay out funds for the merchandise until the documents have arrived and all conditions stated in the LC have been satisfied (Hill, 2001). However, the drawback for the importer is the fee he/she must pay to the issuing bank for the LC. Also, since the LC is a financial liability against him/her, it may reduce his/her ability to borrow funds for other purposes.

\section{Sight and Time Drafts}

According to Hill (2001), a draft is simply an order written by an exporter instructing an importer or an importer's agent to pay a specified amount of money at a specified time. The buyer's ability or willingness to pay could change between the time goods are shipped and the time the drafts are presented for payment. Also, the policies of the importing country could change. Madura (2003) also defines a draft as an unconditional promise drawn by one party, usually the exporter, instructing the buyer to pay the face amount of the draft upon presentation. The draft represents the exporter's formal demand for payment from the buyer. A draft however, affords the exporter less protection than an LC since the banks are not obligated to honour payments on the buyer's behalf.

There are two categories of draft; sight drafts and time drafts. Sight drafts, known as documents against payment or cash against documents, must be paid upon presentation. While this characteristic makes a sight draft seemingly similar to a cheque, a sight draft generally requires supporting documents showing that the terms of the underlying transaction have been met. From the importer's standpoint, sight drafts are beneficial because the importer does not have to pay for the goods until they arrive. Sight drafts are advantageous to exporters primarily because exporters retain title to the goods until the importer pays the draft. However, sight drafts are risky to exporters in the event that the importer refuses to pay for the merchandise (Dennis, 1993). Time drafts, referred to as documents against acceptance or documents against issuance are also payable subject to documentation and are processed similarly to sight drafts. However, time drafts are not required to be paid until a specific time in the future. Time drafts are risky for the exporter because the seller must rely on the buyer to return to the bank to make payment after taking title of the goods (Dennis, 1993). Essentially, a time draft is a method of seller-supported financing in which the seller relinquishes control of the goods in return for a signature on the acceptance to assure him/her of payment (Shapiro, 2002).

\section{Documentary Collections}

The documentary collections method is in essence a time draft (discussed above), with documents required before payment is made. In the documentary collections process, the banking system serves as the transfer agent. The advantage is that the seller is protected because title to the goods is not transferred to the buyer until payment has been made, or until the seller is convinced that payment will be made. The disadvantages are that payment is buyerinitiated and that by the time payment is made exchange rates may have changed. In addition, the buyer may refuse the shipment. Documentary collection offers a compromise between LCs, which can be expensive, pre-payment which poses a high risk to the importer/buyer and open account which exposes the exporter/seller to a high risk. In a documentary collection transaction, banks on both ends act as intermediaries in the processing of shipping documents and the collection of payment. 


\section{Lockboxes}

These are special post office boxes set up to incept and speed up accounts receivables collections (Ross et al, 2001). The collection process is started by customers mailing their cheques to a post office box instead of sending them to the firm. A local bank maintains the Lockbox. There are no significant differences between domestic and international lockbox operations.

\section{Giro Payments}

A giro (from the Latin "gyre": turn, transfer) is a payment mechanism that allows the direct transfer of funds between giro bank account holders. With a giro payment, the payer hands the payment order directly to his own bank which then makes payment to the recipient's bank. After the payment has been received, his bank notifies the payee. Giro payment cannot bounce because the payee bank simply will not accept the order if there are insufficient funds to cover it. Organisations use giro payments in the areas of receivables management, small cross-border transfers, and payroll services (Oosthoek, 1985). The advantages of giro payments include decreased collection float and low cost. The major disadvantage for the seller is that he or she must wait for the buyer to initiate the giro payment. Giro payments are typically produced manually and lack standardisation (Lang, 1987) and are mostly concentrated in the consumer sector (Hill and Sartoris, 1992).

\section{Cash in Advance}

This method of payment requires the importer to pay the exporter in full before shipment is made (Hill, 2001). Payment is usually made in the form of international wire transfer to the exporter's bank account or foreign bank draft. This method affords the supplier the greatest degree of protection and it is normally requested of first-time buyers whose credit worthiness is unknown or whose countries are in financial difficulty. If currency is thought to appreciate, then prepaying enables the company to pay at a lower rate. If the future rate finally depreciates, the firm is worse off than if it had done nothing. This method poses a big risk to the importer as he/she depends totally on the integrity of the exporter but offers the greatest protection for exporters because no credit extension is required. The primary disadvantage of prepayment is that it can limit the exporter's sales potential (Dennis, 1993).

\section{Value Dating}

Value dating is the method used to determine on what day a credited or debited amount is incurred in the computation of interest. The value dating rules for funds transfer differs from those applied to, for example, debit card payments in shops or cash dispenser withdrawals. It has two components: forward value and back value. Forward value refers to the situation in which a bank credits a deposit after the date of deposit, and is analogous to placing float on deposited cheques in the U.S. banking system (Hill \& Sartoris, 1992). Back value refers to the situation in which the bank debits a withdrawal from a payor's account prior to the date of presentation on the payor's account (Seeman, 1992). In both cases, the firm's float is adversely affected. Banks often use value dating as a secondary means of earning compensation (Maness \& Zietlow, 1993). 


\section{International Factoring}

The method involves selling of receivables to a financial institution, the factor, usually without recourse. Factoring is the discounting of foreign accounts receivables that does not involve a draft. The exporter transfers title of his/her foreign accounts to a factoring house for cash at a discount from the face value. Factoring allows a firm to eliminate its own credit department and the associated costs. Again, it provides a firm with substantial flexibility. However, there are certain costs associated with it; the factor receives a commission on the face value of the receivables. If the factor advances money to the firm, then the firm must pay interest on the advance. Factoring can be used to reduce the risk of open account sales because factors preapprove buyers before shipment. Factors are generally associated with affiliates or other factors in the importers' countries (Philbrick, 1994).

Factoring has several limitations. For instance, export factoring is not necessarily suitable for companies that are new to exporting; it is more appropriate for companies experienced in exporting who would like to reduce their risk of selling on open account. Additionally, factors will not accept clients for one-time deals, and often require a minimum volume of business from an export company (Ashuri, 1994). Moreover, factors generally will not factor receivables that involve developing countries due to their inadequate legal and financial frameworks (Ring, 1993). In addition, the benefits of factoring may be outweighed by the high costs, which can be as great as 1.75 to $2 \%$ of sales (Shapiro, 2002).

\section{RESEARCH METHODOLOGY}

This study sampled the top 100 exporting firms from the Ghana Export Promotion Council database of exporters. The firms were selected based on the volume of export sales. The sample included both Ghanaian exporting firms and foreign companies (subsidiaries of foreign firms in Ghana) in the sample. This article seeks to ascertain the extent to which firms involved in international trade use international working capital management vehicles. The survey instrument basically involved a closed-ended questionnaire, that is, "questions that can be answered by simply checking a box or circling the proper response from a set provided by the researcher" (Fowler, 1993). While this method allows for easier analysis of the data due to standardised questions, its limitation is that it allows the researcher to determine only what the respondents are doing, not how or why they are doing it. Out of the 100 questionnaires sent, 59 responses were received, representing a response rate of $59 \%$. The study focuses on two areas of working capital management: international cash management operations and international cash collection and credit management practices. Responses were measured with a Likert-type rating scale. This helped in determining the extent to which the firms use international working capital vehicles. Data obtained from respondents was entered into an "SPSS" database application for analysis. Descriptive statistics were basically used in the presentation and analysis of empirical results

\section{RESULTS AND DISCUSSION}

\section{Profile of Sampled Firms}

Table I presents the characteristics of the firms based on industry classification, size, age and ownership. In all, three industries were represented including manufacturing representing $57.6 \%$ of valid respondents, trading $(28.8 \%)$ and service (13.6\%). Three size categories were defined on the basis of number of employees. Firms with less than 30 employees were classified as small 
firms. Medium sized firms had between 30 and 99 employees and large firms had more than 100 workers. About $8(13.6 \%)$ of the firms surveyed were in the small firm group, $12(20.3 \%)$ were medium sized companies and $39(66.1 \%)$ were in the large scale group. The firms were also categorised on the basis of date of establishment. Firms which have been in business for less than 6 years were labeled "young", those between 6 and 10 years were classified "adult" and those over 10 years were also labeled "mature". There were 8 (13.6\%) young businesses. Adult firms were 8 representing $13.6 \%$ while mature companies were $43(72.8 \%)$. Average size and age were 96 and 8 respectively. Most (64.4\%) of the firms were Ghanaian owned and the remaining $35.6 \%$ had some foreign participation in the firms. Among those with foreign participation, 15 were subsidiaries of multinational companies.

Table 1: Characteristics of Sampled Firms

\begin{tabular}{lcc}
\hline Industry & Frequency & Percentage \\
Manufacturing & 34 & 57.6 \\
Trading & 17 & 28.8 \\
Service & 8 & 13.6 \\
Total & 59 & 100.0 \\
& & \\
Size & & \\
Small & 8 & 13.6 \\
Medium & 12 & 20.3 \\
Large & 39 & 66.1 \\
Total & 59 & 100.0 \\
& & \\
Age & & \\
Young & 8 & 13.6 \\
Adult & 8 & 13.6 \\
Mature & 43 & 72.8 \\
Total & 59 & 100.0 \\
& & \\
Ownership & & \\
Wholly Ghanaian-owned & 38 & 64.4 \\
Foreign-participation & 21 & 35.6 \\
Total & 59 & 100.0 \\
Source: Survey data. & & \\
\hline
\end{tabular}

Table 2 shows the international trade activities of the sampled firms. Nineteen (32.2\%) have international sales of less than $26 \%$. Seventeen $(28.8 \%)$ reported that their international sales constitute between $26 \%$ and $50 \%$. Thirteen $(22.1 \%$ ) also have international sales between $51 \%$ and $75 \%$ of total sales. Also, ten firms representing $16.9 \%$ of respondents indicated that their international sales constitute over $75 \%$ of total sales. The majority $(61.1 \%)$ of the respondents also import over $75 \%$ of their inputs from outside. As shown in table 2, $64.3 \%$ of the firms have accounts with less than 5 foreign banks and $50.8 \%$ also have relationships with less than 5 foreign banks. 
Table 2: International Trade Activities

\begin{tabular}{lcr}
\hline Percentage of Overseas Sales & $\begin{array}{c}\text { Frequency } \\
\text { Percentage }\end{array}$ \\
$26-50$ & 19 & 32.2 \\
$51-75$ & 17 & 28.8 \\
$76-100$ & 13 & 22.1 \\
Total & 10 & 16.9 \\
& 59 & 100.0 \\
Percentage of Foreign Imports & & \\
Less than 26 & & \\
$26-50$ & 0 & 0 \\
$51-75$ & 12 & 20.3 \\
$76-100$ & 11 & 18.6 \\
Total & 36 & 61.1 \\
& 59 & 100.0 \\
Number of Foreign Bank Accounts & & \\
None & & \\
$<5$ & 21 & 35.6 \\
$5-10$ & 38 & 64.4 \\
$11-30$ & 0 & 0 \\
Over 30 & 0 & 0 \\
Total & 59 & 100.0 \\
Relationship with Foreign Banks & & \\
None & & \\
$<5$ & & \\
$5-10$ & 25 & 42.4 \\
$11-30$ & 30 & 50.8 \\
Over 30 & 0 & 0 \\
Total & 4 & 6.8 \\
& 0 & 0 \\
Source: Survey data. & 59 & 100.0 \\
& & \\
\hline
\end{tabular}

\section{International Cash Management Operations}

Table 3 indicates that $50 \%$ of the respondents use wire transfer often while $28.6 \%$ never use them. This suggests that more than half of the sampled firms use wire transfers. A mean of 1.86 suggests a relatively high use of wire transfers among Ghanaian exporters. In spite of the global awareness and use of electronic funds transfer, Ghanaian firms do not report high use of them. As can be seen in table $3,35.7 \%$ of respondents often use electronic funds transfers, while $21.4 \%$ never use the payment method. A mean value of 1.50 is just satisfactory. The results also show that no firm uses payment netting often, while $32.9 \%$ have never used it. Apart from the low level of international business and inter-affiliate activities among Ghanaian firms, the system is a relatively new phenomenon even among the advanced countries. In ascertaining the use of cash pooling, the study limited that to only multinational firms in the study sample given that the cash pooling technique is mainly used by multinational companies. As shown in table $3,13.3 \%$ of 15 multinational firms often use cash pooling, while $26.7 \%$ never use it. In spite of the benefits of cash pooling, multinational firms in Ghana rarely use this international working capital vehicle. 
Table 3: International Cash Management Operations

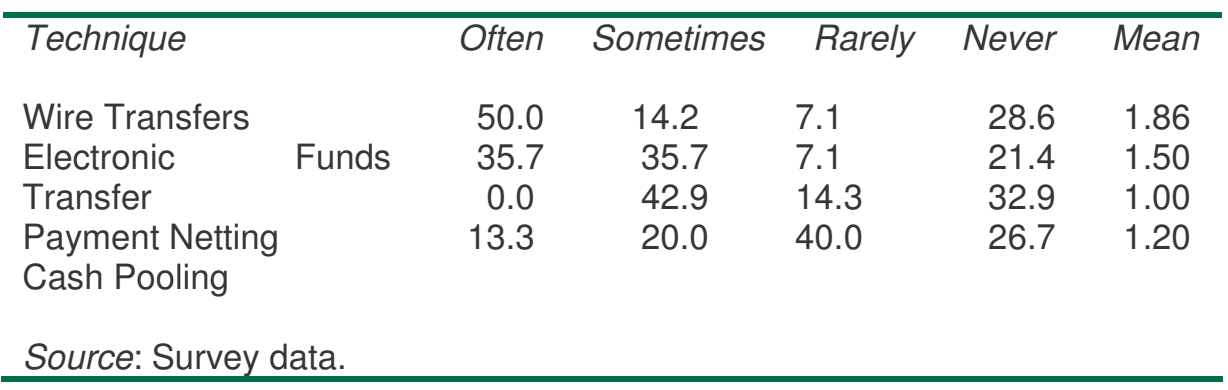

\section{International Sales and Collection Activities}

The use of open accounts among Ghanaian firms is very significant. Table 4 indicates that $45.5 \%$ of respondents often use open accounts while $18.2 \%$ have never used it. A mean of 2.0 is quite high. With respect to consignment, most firms are careful in adopting this tool in their international sales. The reason clearly is the foreign exchange rate risk the exporter would have to bear until the goods are sold by the importer. In this Ghanaian study, the results show that $18.2 \%$ often sell on consignment, $9.1 \%$ sometimes use it, and the majority $(72.7 \%)$ never use it. The mean value of 0.73 suggests low patronage of this system.

While letters of credit may be used domestically, they are more commonly used internationally. The survey results, as indicated in table 4 , show that $61.5 \%$ of the respondents employ letters of credit often; $16 \%$ never use this system. Sight drafts must be paid upon presentation of the draft and supporting documents. Time drafts are also payable subject to documentation and are processed similarly to sight drafts. As depicted in table 4, only a few of the respondents reported never using sight and time drafts: only 10\% mentioned they never use sight and time drafts, $33.3 \%$ often use it, $28.6 \%$ sometimes use it, while $21.4 \%$ rarely use it. The documentary collections method is similar to time drafts with documents required before payment is made. The results show that $20.6 \%$ of the respondents never use documentary collections, $21.4 \%$ rarely use it, $27.3 \%$ sometimes use it, while $30.7 \%$ often use it. The mean values of 2.22 for sight and time drafts and 1.84 for documentary collections are quite high.

In international lockbox arrangements, firms simply employ banks located in foreign countries to collect their international payments. The use of this system among Ghanaian firms is insignificant. From table $4,42.8 \%$ of the respondents reported they have never used lockboxes but no firm uses the system often. A mean of 0.50 clearly suggests very low use of this system. Giro Payment is also used by firms in the areas of receivables management, small cross-border transfers and payroll services. Table 4 indicates that only $7.1 \%$ of the respondents use Giro payment often, while $42.9 \%$ never use it. Cash in advance payment system offers the greatest protection for exporters because the goods are prepaid and no credit is given to the importer. The flip side however, is that it can limit the exporter's sales potential. Importers may seek products from competitors with more flexible payment terms rather than make upfront payments or payment in advance. In this survey, the results show that only $28.6 \%$ of the respondents often use cash in advance, $28.6 \%$ sometimes use it and $7.1 \%$ rarely use it. Quite a number $(35.7 \%)$ of the respondents never use it. 
The value dating system is not common in the Ghanaian banking system. As can be seen in table 4 , only $7.1 \%$ of the respondents often use value dating; half of the respondents reported never use it. In spite of the benefits of factoring, Ghanaian firms showed low use of it. The results of this survey, as illustrated in table 4 , show that $64.3 \%$ of the respondents have never used factoring. Only $21.4 \%$ indicated they sometimes use it. The low mean value of 0.73 confirms this. The reason may also be due to the reluctance of factors to factor receivables that involve developing countries due to their inadequate legal and financial frameworks (Ring, 1993).

Table 4: International Sales and Collection Activities

\begin{tabular}{|c|c|c|c|c|c|}
\hline Technique & Often & Sometimes & Rarely & Never & Mean \\
\hline Open Accounts & 45.5 & 27.2 & 9.1 & 18.2 & 2.00 \\
\hline Consignment & 18.2 & 9.1 & 0.0 & 72.7 & 0.73 \\
\hline Letters of Credit & 61.5 & 15.4 & 7.1 & 16.0 & 2.22 \\
\hline Sight and Time Draft & 33.3 & 28.6 & 28.1 & 10.0 & 1.84 \\
\hline Documentary & 30.7 & 27.3 & 21.4 & 20.6 & 1.68 \\
\hline Collections & 0.0 & 14.3 & 21.4 & 42.9 & 0.50 \\
\hline Lockboxes & 7.1 & 14.3 & 14.3 & 42.9 & 0.64 \\
\hline Giro system & 28.6 & 28.6 & 7.1 & 35.7 & 1.49 \\
\hline Cash in Advance & 7.1 & 21.4 & 7.1 & 50.0 & 0.73 \\
\hline $\begin{array}{l}\text { Value Dating } \\
\text { Factoring }\end{array}$ & 0.0 & 21.4 & 0.0 & 64.3 & 0.64 \\
\hline Source: Survey data. & & & & & \\
\hline
\end{tabular}

\section{CONCLUSION AND RECOMMENDATIONS}

This article investigates the international working capital practices of Ghanaian firms involved in international trade. The objective of the study is to ascertain the extent of use of the international working capital management vehicles among Ghanaian firms. The article focuses on two areas of international working capital management; international cash management and international sales and accounts receivables management. The results of this study show that, apart from Wire Transfers and Electronic Funds Transfers, Ghanaian firms exhibit low use of the international cash management. The results also indicate that Ghanaian firms mainly use Letters of credit, Sight and Time Draft, and Documentary Collections in their international sales activities. Overall, Ghanaian firms show a low level of use of international working capital techniques. The reasons could be attributed to the low level of education and sophistication among finance and treasury personnel and also because of the under-developed financial markets in Ghana. The elaborate documentations, risks and costs involved in using these vehicles are also contributory factors. More importantly, the results could be explained by the fact that very few Ghanaian firms have internationalised their operations. Some of the international working capital management vehicles are more relevant to firms that have foreign subsidiaries. It is not surprising therefore that, Ghanaian firms exhibit a low level of use of these vehicles. Apart from Ashanti Goldfields Ltd (now AgloAshanti) and Ghana Commercial Bank, no Ghanaian firm has progressed to the point of establishing foreign subsidiaries. Applying the stages model, Ghanaian firms can be said to be at their early stages of internationalisation, since they are mainly involved in imports and exports. It is recommended that internationally oriented firms in Ghana must learn about these international working capital techniques and begin to adopt them in their operations. Ghanaian 
banks should also educate their clients on the importance of such techniques in their international working capital management.

\section{REFERENCES}

Abor J. 2004. Working Capital Management and Corporate Profitability: Evidence from Ghana. LBS Management Review, 9(1): 32-45.

Aggarwal R \& Baker J. 1991. SWIFT as an International Funds Transfer Mechanism: User Satisfaction and Challenges. Advances in Working Capital Management, 2: 269-289.

Ashuri A. 1994. The Factor Factor. World Trade, 7:7 (August): 34-37.

Baker HK. 1987. Financial Management. New York: Harcourt Brace Jovanovich College Publishers.

Bogusz R. 1993. The Renaissance of Netting. Journal of Cash Management, 13 (3): 10-13, 16 17.

Brown J. 1989. Exports Fly High as Government Programs Offer Financial Aid. Corporate Cashflow, 10(7): 29-34.

Clark E, Levasseur M \& Rousseau P. 1993. International Finance. London: International Thomson Business Press.

Collins JM \& Frankle A. 1985. International cash management practices of large U.S. firms. Journal of Cash Management, 5(4): 42-48.

Cunningham S \& Porter AJ. 1992. Communication networks: a dozen ways they'll change our lives. The Futurist, 26(1): 19-22.

Dennis MC. 1993. Exporters Can Choose Different Terms of Sale. Business Credit, 95(6): 40-41.

Fowler F. 1993. Survey Research Methods. California: Sage Publications.

Hill N \& Sartoris W. 1992. Short-term Financial Management. New York: Macmillan.

Hill CWL. 2001. International Business; Competing in the Global Marketplace. Boston: Irwin/McGraw-Hill.

Kress HG. 1991. Who Bears the Liability for Errors in Electronic Funds Transfers? Banking Law Review, 4(2): 5-9.

Lang EA III. 1987. Treasury management in the UK. Cashflow, 8(4): 42-45.

Madura J. 2003. International Financial Management. Boston: South-Western College Publishing.

Maness T \& Zietlow J. 1993. Short-Term Financial Management. Minneapolis/St. Paul, MN, West, 515. 
Oosthoek W. 1985. European girobanks: what they are and how to use them. Journal of Cash Management, 5(1): 22-24.

Philbrick WC. 1994. The Use of Factoring in International Commercial Transactions and the Need for Legal Uniformity as Applied to Factoring Transactions Between the United States and Japan. Commercial Law Journal, 9(1): 141-156.

Ricci C \& Morrison G. 1996. International working capital practices of the Fortune 200. Financial Practice and Education, 6(2): 7-20

Ricci C \& Vito ND. 2000. International working capital practices in the UK. European Financial Management, 6(1): 69-84.

Ring MA. 1993. Innovative Export Financing: Factoring and Forfeiting. Business America, 114(2): $12-14$.

Ross SA, Westerfield RW \& Jordan BD. 2001. Essentials of Corporate Finance. McGrawHill/Irwin.

Seeman W. 1992. Banking Systems of Six Selected Countries. Journal of Cash Management, 1(2): 18-22.

Shapiro AC. 1978. Payments Netting In International Cash Management. Journal of International Business Studies, 9(2): 51-58.

Shapiro AC. 2002. Multinational Financial Management. New York: John Wiley \& Sons Inc.

Shin H \& Soenen L. 1998. Efficiency of Working Capital and Corporate Profitability. Financial Practice and Education, 8(2): 37-45.

Wagner C \& Schumacher H. 1994. Managing Commercial Risk. Risk Management, 41(4): 83.

Williams SL. 1988. Political and Other Risk Insurance: Eximbank, OPIC and MIGA. Part III: Eximbank. Middle East Executive Reports, 11(5): 23-25. 